\title{
Achieving National Water Sustainability by Improving Soil Organic Matter Content
}

\author{
Dr N Vivek* \\ $\left\{\right.$ vivek@psgim.ac.in $\left.{ }^{1}\right\}$ \\ *Professor, PSG Institute of Management, PSG College of Technology, Peelamedu, Coimbatore, \\ Tamilnadu
}

\begin{abstract}
Agriculture happens to be the major water consumer in most nations and particularly in developing nations. To ensure sustainability and availability of water for everyone, we need to plan water usage in agriculture properly. One neglected factor is the soil water holding capacity, which if managed properly, will lead to less watering needs and hence reduce the water usage in agriculture by adequate levels to ensure a sustainable water supply in the nation. This method is not just a conceptual idea, but also an achievable one by improving the soil organic matter content of soil..
\end{abstract}

Keywords: Soil organic matter, humus, water holding capacity, mulch, biochar, Indegenous microorganisms, nursery soil, terra preta, runoff, soil compaction.

\section{Introduction}

The problem with Water Usage patterns and available supply

India is blessed with a regular and adequate monsoon each year that feeds most of the nation with adequate water supplies. This water partly feeds rivers, lakes, underground aquifers and runoffs. Statistics shows that a bulk of the received rainwater of around 4,000 $\mathrm{BCM}(3,000 \mathrm{BCM}$ in monsoon alone) around 2,000 $\mathrm{BCM}$ accounts for the runoff alone (Central Water Commision, 2020). The amount of water flowing into all of these water bodies is connected to the quality of the soil. And among the various variables having an impact on water absorption into the earth, the un-noticed variable happens to be soil organic matter. This is all the more critical because in developed countries around $68 \%$ of water goes for irrigating crops while in developing countries this goes up to $80 \%$ or more. Agricultural usage of water has grown faster than the replenishment of natural resources due to factors like new hybrid seeds usage, large fertiliser use that kills off soil micro flora and fauna, Large machine usage that creates soil compaction three to five feet below the surface which cannot be broken even by modern tilling discs and tractors(Dhavan, 2017). As a result modern agriculture is using more than 8 times the water used for the same crops since ancient times. While the yields seem to be higher, this is not necessarily the case in each and every crop. Also it has been difficult for farmers to maintain the increased yields year on year and over time the yields drop to the old levels, which brings us to question the very premise of using modern hybrid seeds even though they consume huge amounts of water. This was attributed to weeds (Gharde et al, 2018). The fact that allows weeds to thrive while affecting regular crops is the quality of soil and microbial content of the soil. The most important component happens to be humus. In poor soils the amount of mycorrhizal fungi is depleted due to the absence of adequate soil 
organic matter. This means only a few colonies of bacteria survive that are ideal only for weeds to grow and not regular crops (Asplund et al, 2019). This was further observed to be the case by comparing the soils with those of undisturbed mountain soils which showed a huge population of fungi, often 9 to 10 times that of the bacterial colonies (Wang et al, 2021). This leads us to propose the following

H1: The microbial balance of fungi and bacteria shows the quality of the soil and decides which kind of crop can grow in which type of land.

Now the kind of soil organic matter that generates humus is dry matter with the right kind of moisture and this is achieved by fungal decomposition. In olden days this was available in abundance due to the presence of trees in each field, which has now been reduced to a bare minimum. We still are able to guess this connection because of studying the fertile forest floors and identifying the soil contents there (Wang et al, 2021). This leads us to hypothesise

H2: Trees play a crucial role in introducing and maintaining soil organic matter in right proportions needed to grow any kind of crops

Bayrandvand et al (2021) also propose something similar by studying various soil micro flora and fauna content at various altitudes and invariably the conclusion is the same, meaning the fungal content decides the humus content of the soil. And the tree connection is most unexpected here. This points to hardy species of native indian trees like ficusreligiosa, pongamiapinnata, all kinds of bamboos, etc as a possible remedy for soil microbial adequacy by supplying the right kind of organic matter.

\section{Impact of soil organic matter content on green water}

Soils poor in humus content usually have soil compaction and are chief causes of water runoff losses. This humus is an outcome of soil organic matter which breaks down into humus. Good soil has three major characteristics of porosity, water retention and nutrition to make it cultivation worthy. Good decomposed organic matter with the right mix of green and dry matter gives a compost with the right mix of bacteria and fungus and results in this type of desirable soil which has the right amount of porosity for the roots of plants to grow in abundance, right water holding capacity to ensure soil moisture is adequate for the plants to thrive and also to maintain a microclimate for the plants and tree roots to be healthy and allow the rot zone to be a breeding ground for symbiotic fauna and flora (Chang et al, 2021). This kind of soil results in adequate and sustainable infiltration of water to ensure that most of the rain water and flowing water is retained and the loss of topsoil is reduced to a minimum possible level. The major point here is that irrespective of what is growing in the land, it is the soil organic matter level that decides the water holding capacity of the soil.

Libohova et al(2018) mention how soil organic matter impacts water holding capacity of the soil. They had determined the average water holding capacity of soil precisely. They suggest that for an acre of land, for each $1 \%$ increase in soil organic matter, the water holding capacity is around 10,800 liters assuming a $15 \mathrm{~cm}$ thickness layer of the soil. So if the land has $4 \%$ organic matter it translates to a water holding capacity of 43,200 liters for every acre. This is usually the once a week watering done to fields. Here the fields need not be watered each day as the soil holds the water for long periods of time due to soil organic matter. This organic matter can hold upto five times its volume in water. This leads us to the following hypothesis

H3: To improve water holding capacity and infiltration capacity, it is essential to increase soil humus levels. 
H4: Soil fungus plays a crucial role in creating soil humus and hence improving the soil organic matter.

Most degraded lands have organic matter composition of less than $0.5 \%$ which is the primary cause for not being able to capture the rainfall that India gets regularly. If this were worked on, they the entire water requirement and absorbing capacity of soil would drastically change to create a more sustainable world.

\section{Methods to improve soil organic matter}

Ali et al (2020) have spoken about horti pastoral systems and the effectiveness of using multiple trenches in the land to capture runoffs. They computed the optimum number of trenches per acre to be 375 which led to increase in soil organic matter by 0.8 to 2.2 times the pre intervention levels. The lands selected by them were extremely degraded Ravine terrains which accounts for runoff of 11 to $22 \%$ of monsoon rainfall. Further this study assumed a lack of acceptance of the cost intensive measures like levelling and terracing that are popular in most hilly terrains. The unnoticed point here is the improvement in soil organic matter, which alone could improve the water holding capacity of the land by many times the volume of the organic matter. This has also increased the fertility of the soil many fold.

Nghia (2020) showed the value of using Indegenous microorganisms to kickstart the humus development process in any soil as proposed by Dr Cho Han Kyu after rigorous research and testing on multiple farms across the world. This method collects local microbes from nearby mountains that have undisturbed forests and introduces them into fields along with organic matter and compost to kickstart the soil organic matter development process. This is one of the quickest methods to get soil biology back in action, in the soil. This method makes use of rice and wheat bran to work like a prebiotic and feed the probiotics for the soil. In the course of a few months the soil structure gradually changes to the form and quality of the mountain soils. Here too the key point is mountain forests which have been left undisturbed. This stresses on local varieties of trees. Cho(2018) simplified this process by directly preparing a spore solution from the leaf mold soil that is collected from the mountains (JADAM microbial solution of JMS) and applied it as soil drench and as foliar sprays to ensure a proper biodiversity, but mentions that this process would be effective only if the microbes have a proper living environment in the soil. For this the suggestion is to add wild grasses, crop residue, saw dust, wood chips, and any organic matter in general. The two together generate good quality humus within a year. Most soils generate $4 \%$ to $5 \%$ humus within a year's time. Young Sang Cho also suggests many do it yourself solutions that he calls JADAM liquid fertiliser, each of which show very high levels of organic matter (especially the fish liquid fertiliser solutions made from fish waste which show between $4 \%$ to $10 \%$ organic matter)

Singh and Sahadeo (2020) have mentioned another approach developed by Prof S A Dabholkar, who used the principles of mathematics to come up with a concept called nursery soil. He has defined ideal soil or nursery soil as one composed of $50 \%$ mud and $50 \%$ decomposed organic matter by volume. He was the first person to measure soil composition by volume, while others used weight to measure the components. He had demonstrated the ability to generate good humus rich soil within 100 days. This soil needs very little watering (one tenth of regular soil), has at least $4.5 \%$ organic matter and does not get soggy during 
heavy rains. It absorbs most of the precipitation it gets and usually creates very deep soil with a highly porous structure as does the method suggested by Cho hanKyu.

Seymour and Utter (2021) suggest another near forgotten method which was suggested and used by Ms Ruth Stout. She is known as the mulch queen who did a no effort farming method for over 50 years. Her method involved adding straw mulch over her vegetable plots to a height of one foot just before winter. Winter snow would cover the straw and wet it fully leading to a decomposing of the lower levels leading to formation of fungally dominated soil that did not need ploughing, digging or even watering for over 50 years. Her methods, though seemingly against common sense, were well tested by conventional scientists and validated for efficacy time and again. What she demonstrated was, to improve soil organic matter, just cover the earth with a deep layer of mulch at least a foot deep and make sure it is drenched. It will slowly yield a soil of great texture with at least $4 \%$ organic matter. Her plots always teemed with earthworms within a short period of a few months. And importantly, her plots never got flooded any time, because her soil always absorbed all of that with minimal fuss.

Putri and Panji (2021) brought to light an ancient concept that is known to us today as terra preta, also translated as black earth in Portuguese by the people who discovered it. In the Amazon basin, the soil is yellowish in nature and contains too much aluminium oxide. So nothing can grow. But in this very place, two amazing contra events have taken place. One is the thick amazon forest that grows entirely on the leaf mold layer that has developed over the years to such a thickness, that even the heaviest rains are captured to provide adequate moisture for the vegetation to survive the humid summers effortlessly. This corresponds to the methods mentioned previously that use leaf mold in some form or the other. The next method however is not only strange, but also shrouded in mystery. In the same amazonian jungle there are areas where the yellow mud turns pitch black. On examination it turned out to be charcoal which was man made. Some unknown set of humans, over 4,000 years back dug trenches and filled it with charcoal and all kinds of bio wastes. This process was so effective, that it retains all the properties of super productive soils even now after thousands of years, in spite of having a dense forest growing over it, and not losing any nutrients. This was such an interesting concept that a successful experiment was conducted on degraded ex gold mining land in Sumatra using rice husk biochar as the organic matter enhancer. They found 30 tons/hectare to give the best results. Rice husks biochar being a waste product in most rice mills come very cheap and are easy to procure.

The above discussions lead us to the following hypothesis

H5: Soil organic matter will not increase automatically. It needs careful work and planning to accomplish on a large scale, but is not impossible or difficult to attain if executed systematically.

\section{Conclusion}

Soil organic matter is the key to water retention in both cultivated and barren lands. Every percent increase in organic matter content improves water holding capacity by over 10,000 liters. This will reduce water requirements of the land, reduce runoffs of rainfall water, improve soil moisture content, increase the water table by replenishing the subterranean aquifers and finally lead to a highly productive soil that grows crops and trees without the need for external fertilisers. There are many methods for improving soil organic matter, but each one needs careful planning and execution so that the soil regeneration happens at the 
quickest pace, thereby changing the entire supply demand characteristics of water for agricultural lands. This huge issue being sorted out will lead to water being available for other uses like industries and new townships.

\section{References}

[1] Ali, S., Sethy, B. K., Parandiyal, A. K., Kumar, A., Singh, R. K., Somasundaram, J., \& Mina, B. L. (2020). Long-term effects of rainwater conservation measure on improving yield, runoff use efficiency and soil properties of horti-pastoral system on the degraded ravine lands of India. Agricultural Water Management, 233, 106068.

[2] Asplund, J., Kauserud, H., Ohlson, M., \&Nybakken, L. (2019). Spruce and beech as local determinants of forest fungal community structure in litter, humus and mineral soil. FEMS microbiology ecology, 95(2), fiy232.

[3] Bayranvand, M., Akbarinia, M., SalehiJouzani, G., Gharechahi, J., Kooch, Y., \&Baldrian, P. (2021). Composition of soil bacterial and fungal communities in relation to vegetation composition and soil characteristics along an altitudinal gradient. FEMS Microbiology Ecology, 97(1), fiaa201.

[4] Central water commission (2020), http://www.cwc.gov.in/water-info\#1

[5] Chang, Z., Ye, X., \& Zhang, J. (2021). Soil water infiltration of subalpine shrub forest in Qilian Mountains, Northwest of China. Agronomy Journal, 113(2), 829-839.

[6] Cho, Y. (2018). JADAM Organic Farming: ULTRA Powerful Pest and Disease Control Solution, Make all-Natural Pesticide, The way to Ultra-Low-Cost agriculture!. JADAM.

[7] Dhawan, V. (2017, January). Water and agriculture in India. In Background paper for the South Asia expert panel during the Global Forum for Food and Agriculture (Vol. 28).

[8] Gharde, Y., Singh, P. K., Dubey, R. P., \& Gupta, P. K. (2018). Assessment of yield and economic losses in agriculture due to weeds in India. Crop Protection, 107, 12-18.

[9] Libohova, Z., Seybold, C., Wysocki, D., Wills, S., Schoeneberger, P., Williams, C., ...\& Owens, P. R. (2018). Reevaluating the effects of soil organic matter and other properties on available waterholding capacity using the National Cooperative Soil Survey Characterization Database. Journal of Soil and Water Conservation, 73(4), 411-421.

[10] Putri, E. L., \&Panji, R. (2021, May). Improvement of nutrient status in ex-gold mining land with the application of rice terra pretabiochar technology. In IOP Conference Series: Earth and Environmental Science (Vol. 741, No. 1, p. 012031). IOP Publishing.

[11] Singh, M., \&Sahdeo, S. N. (2020). Role of Indigenous Cows in the Development of Farmerfriendly Organic Farming Technologies by Agricultural Institutions.Asian Agri-History, 24(2).

[12] Nghia, N. K. (2020). Microbial diversity of indigenous microorganism communities from different agri-ecosystems in SocTrang province, Vietnam. ENGINEERING AND TECHNOLOGY, 10(1), 53-64.

[13] Seymour, M., \& Utter, A. (2021). Veganic farming in the United States: farmer perceptions, motivations, and experiences. Agriculture and Human Values, 1-21.

[14] Wang, N., Fu, Q., Zhou, Z., Shao, Y., Wang, J., Li, W., ...\& Yuan, Z. (2021). Humus microhabitat affects distributions of soil fungi and bacteria in a temperate mountain forest. Ecology and Evolution.

[15] D.S. Vijayan, D. Parthiban," Effect of Solid waste based stabilizing material for strengthening of Expansive soil- A review," Environmental Technology \& Innovation, Volume 20, 2020, 101108, ISSN 2352-1864, https://doi.org/10.1016/j.eti.2020.101108 